\title{
Gilberto Freyre e a Valorização da Província
}

Lucia Lippi Oliveira

Resumo: O artigo apresenta as diferentes leituras da obra de Gilberto Freyre dos anos 1930 até os dias atuais. Mostra a importância de suas experiências como viajante para a adoção de uma perspectiva endógena e exógena de olhar as cidades. Reforça o impacto de seu retorno a Pernambuco nos anos 1920 quando o autor se defronta com processo de urbanização que ameaçava descaracterizar o velho Recife. Sua visão patrimonialista ganha concretude na organização do Livro do Nordeste (1925), comemorativo dos 100 anos do jornal "Diário de Pernambuco", onde Manuel Bandeira publica "Evocação do Recife". Freyre e Bandeira, amigos próximos, companheiros de jornada, pode-se dizer revezam-se escrevendo guias e poemas sobre cidades. Por fim, o artigo retoma os conceitos de "modernismo regionalista" ou "provincialização modernista" para identificar em Gilberto Freyre um "outro" modernismo, distinto daqueles que se desdobram do modernismo paulista.

Palavras-chave: Invenção do Nordeste, Viagens em Gilberto Freyre, Guia de Cidades, Regionalismo, Um “Outro” Modernismo.

N ão é possível conhecer como se deu o processo de invenção do Nordeste sem passar pela obra de Gilberto Freyre. E, como abordar GF sem dedicar-se a fazer um estudo profundo de sua obra? Autor e obra estão merecendo novas leituras produzidas e publicadas a partir das comemorações dos 100 anos de nascimento de Freyre, em 2000. Resolvi então percorrer alguns desses textos, muitos deles produzidos para o Seminário Internacional Novo Mundo nos Trópicos, realizado no Recife, de 21 a 24 de março de 2000, e para a Jornada de Estudos Gilberto Freyre, realizada na UNESP-Marília, de 6 a 9 de novembro de 2000. O CD-ROM com os Anais do Seminário e o livro Gilberto Freyre em Quatro Tempos reúnem textos da maioria dos estudiosos sobre Freyre. Novos livros foram também publicados desde então, como o de Maria Lúcia Pallares-Burke, Gilberto Freyre: um vitoriano nos trópicos (2005), e o de Guillermo Giucci e Enrique Larreta, Gilberto Freyre: uma biografia cultural, formação de um intelectual brasileiro 1900-1936 (2007), autores que estão presentes com artigos nos eventos acima referidos.

O impacto da obra de Freyre nos dias atuais pode também ser percebido
1. Pesquisadora e profssora da Fundação Getúlio Vargas - RJ 
pela Exposição “Gilberto Freyre - Intérprete do Brasil” apresentada em 2007 no Museu da Língua Portuguesa, em São Paulo.

Sabemos que houve diferentes recepções à obra de Gilberto Freyre, principalmente Casa Grande \& Senzala, obra considerada como marco para a construção sociológica de uma posição regionalista (SORÁ, 1998). Essa recepção, nomeada de "fortuna crítica", permite acompanhar as transformações no pensamento brasileiro dos anos 1930 até os dias atuais.

Nos anos 1930 e 1940, Gilberto foi aclamado como criador de nova autoimagem positiva do Brasil, que superava o racismo presente em autores como Sílvio Romero, Euclides da Cunha e Oliveira Viana. Fez parte do círculo ampliado que gravitou em torno do Serviço do Patrimônio Histórico e Artístico Nacional (SPHAN), em 1937. Participou de iniciativas dessa agência do governo federal ainda que fizesse oposição ao interventor pernambucano Agamenon Magalhães. Hostilizado pelo interventor federal, Gilberto chegou a ser preso por delito de opinião, sendo acusado de pornográfico e de comunista. Em 1945, com a redemocratização, Agamenon vai compor o quadro de fundadores do PSD e Gilberto vai para a UDN. Apoiou a política do governo Salazarista português nas colônias da África ao desenvolver a categoria de lusotropicalismo, capaz de produzir uma ideologia justificadora do colonialismo português.

Nos anos 1960 e 1970, Freyre é identificado como autor que valoriza a tradição autoritária e conservadora do latifúndio açucareiro do Nordeste, sendo recusado pelos cientistas sociais da Universidade de São Paulo - Florestan Fernandes, Fernando Henrique Cardoso e Otávio Ianni. Foi igualmente repudiado pelo apoio dado aos governos militares, após 1964, no Brasil.

Nos anos 1980, volta a ser recuperado positivamente por ter tratado do cotidiano, da sexualidade (novos objetos) e ter utilizado novas fontes e metodologias em suas pesquisas e livros. É então redescoberto pelos historiadores. Assim, começa a ser reconhecido como um precursor da valorização da vida privada, já que explora o cotidiano, expõe a vida íntima da família patriarcal. Em sua pesquisa para Casa Grande \& Senzala, Gilberto fez uso de diferentes fontes, tais como diários, cartas, livros de viagens, folhetins, autobiografias, confissões, depoimentos pessoais orais e escritos, livros de modinhas, cadernos de receitas, romances, notícia e artigos de jornais, procedimento pouco usual à época.

Vem sendo reconhecido, também, como aquele que "antropologizou" a perspectiva de olhar as cidades. O mundo urbano já fora destacado por Gilberto ao analisar seu papel na decadência do patriciado rural, principalmente em Sobrados e Mocambos (1936). Antes, ele já enfocara a vida das cidades em suas viagens e escrevera artigos para o "Diário de Pernambuco" sobre Nova York, sobre 
a Bahia (Salvador) e sobre o Rio de Janeiro. Essa trilha vai ter, no Guia prático, histórico e sentimental da cidade do Recife, um marco.

Ao empreender essa minha viagem sobre o universo regional em GF, depareime com alguns intérpretes e textos que foram fundamentais na montagem do meu argumento. O tema da viagem, por exemplo, mereceu a atenção de Fernando Nicolazzi, em seu artigo "Gilberto Freyre viajante: olhares seus, olhares alheios" (2006). O espaço da cidade foi tratado por Guillermo Giucci, em seu artigo "Gilberto Freyre: as cidades" (2000), e por José Tavares Correia de Lira, em "Naufrágio e galanteio: viagem, cultura e cidade em Mário de Andrade e Gilberto Freyre" (2005). A relação entre Gilberto Freyre e Manuel Bandeira foi sinalizada por alguns intérpretes, entre eles por Mariza Veloso, no artigo "GF e o horizonte do modernismo" (2000), e por Silvana Moreli Vicente Dias, em "A província, das aporias às experiências repartidas: Gilberto Freyre e Manuel Bandeira no Brasil das décadas de 20 e 30" (2008).

O que vou apresentar aqui é, assim, uma leitura de algumas leituras sobre GF. Voltei a textos de Gilberto Freyre, sendo guiada pelos artigos mencionados e me beneficiando do importante serviço da Biblioteca Virtual Gilberto Freyre, que disponibiliza, aos pesquisadores, a obra do autor.

\section{Gilbero Freyre, o viajante}

Diferentes autores têm destacado a experiência fundamental do exílio e da viagem como educação e reeducação do olhar. Olhar o outro possibilita uma comparação entre o familiar e o desconhecido, entre o similar e o diferente, o que favorece o conhecimento histórico e antropológico. A viagem, ao proporcionar uma separação brusca, possibilita um redimensionamento também do lugar de origem. No regresso, quem volta é um outro que, com olhos renovados, busca (re)conhecer as paisagens outrora vividas. A viagem é, portanto, uma reeducação do olhar.

Vejamos como o próprio Gilberto, no Prefácio de Região e Tradição, assim se refere:

O longo período de estudos no estrangeiro fê-lo ver sua região e a tradição brasileira não só com a simpatia endogâmica de nativo que regressa, mas com olhos de exógeno: enxergando no familiar certo encanto do exótico e, ao mesmo tempo, vendo-o na sua pureza de linhas e na exatidão de suas proporções. Vendo-o criticamente e também com simpatia humana a mais íntima. (Prefácio, Região e Tradição, 1940)

Viagens são referidas, também, pela metáfora da "peregrinação". Wilma Peres Costa a usa para explorar a afinidade entre o processo de formação dos 
intelectuais e a formação do sentimento nacional. Foi no século XIX que a viagem passa a ser considerada como parte da formação e do amadurecimento da sensibilidade, ou seja, como conhecimento do mundo e como autoconhecimento. "O depaysement, ruptura ainda que temporária com as origens tem o poder de ampliar o conhecimento, aprimorar o espírito ou revelar os segredos do mundo" (COSTA, 2003, p. 62).

O conhecimento adquirido pela viagem e também pela memória confere autoridade ao discurso, "Creiam em mim: eu conheço, eu vi". Ter estado lá confere autoridade ao relato (NICOLAZZI, 2006; TUNA, 2003). A memória comparativa, o jogo entre o que se vê e o que já foi visto por outros, permite valorizar o relato de viajantes, as crônicas que já foram escritas em outros tempos e que são usadas nesse diálogo entre passado e presente, entre o local e o universal.

Ricardo Benzaquen de Araújo já sinalizara a importância que GF confere à experiência do olhar de cada viajante, ao criticar os "manuais" de viagem que prescrevem um tipo de olhar a ser adotado. No Guia prático, histórico e sentimental da cidade do Recife, Freyre vai dizer que, para viajar ao Recife, é preciso uma visão "irregular, assimétrica e ao mesmo tempo extremamente próxima e calorosa da cidade", um ritmo lento e errático que atente aos pequenos detaIhes, o que se afigura próximo ao flâneur baudelairiano (ARAUJO, 1994, p. 170).

Ao trabalhar a literatura de viagem, José Tavares Correia de Lira (2005) destaca dois gêneros e dois personagens: o diário e o guia; o viajante e o cicerone. $O$ autor explora os gêneros e os personagens abordando as duas figuras de maior importância na década de 1920: Mário de Andrade e Gilberto Freyre, ou seja, o "turista aprendiz" e o "aprendiz de cicerone". Em seu artigo, vai explorar o fio condutor das viagens de Mário de Andrade em suas variantes de missão cultural, de campanha etnográfica, de visita aos amigos e às terras. E expõe como esse turista particular chega à prática do "despaisamento", conseguindo sentir-se em casa no outro.

Bem, o que nos interessa especialmente aqui se refere ao outro personagem tratado por Lira: Gilberto Freyre. É o GF recém-chegado ao Recife depois de sua temporada na Europa e que se defronta, por assim dizer, com duas cidades: a da infância e aquela que encontra e frente à qual se sente estrangeiro. É frente a esse estranhamento que toma a decisão de ficar e de se integrar com o que há de mais brasileiro.

É preciso lembrar que o Recife estava passando por amplo processo de transformação que envolveu saneamento, demolição, alargamento no porto e na área central. Isso envolveu desapropriações, demolições e a construção de novas avenidas radiais partindo do marco zero. Entre as demolições, são citadas a do Arco da Conceição, em 1913, e a do Arco de Santo Antônio, em 1917. O 
ecletismo arquitetônico tornou-se presente nos novos edifícios então construídos.

O empenho modernizante dos anos 1920 provoca reações contrárias, de preservação e de defesa da região. Há também um posicionamento contra um cosmopolitismo barato, contra a estética do progresso que produz um arremedo, uma caricatura marcada pelo mau gosto. Na contra mão da modernização está a defesa do patrimônio arquitetônico colonial, dos traçados urbanos em ziguezague contra o geometrismo, das árvores próprias da região contra a terrível mania de reformismo.

Todas essas questões foram abordadas por GF e estão presentes nos chamados "artigos numerados" publicados no "Diário de Pernambuco", entre 1924 e 1925.

Segundo Lira, GF ora enfatiza o patrimônio, ora os hábitos cotidianos em detrimento do "absolutismo da higiene e da circulação". Ele deseja incorporar ao espírito de renovação o zelo pelas tradições arquitetônicas, valorizando a proximidade, a adaptação tropical de ruas e praças. O furor modernizante e cosmopolita atinge até a natureza: abatem-se árvores da região em nome de novas, importadas.

É preciso ressaltar que, nos anos 1920, não estava claro que tipo de nova modernidade seria assumida no campo da arquitetura. $O$ importante exemplo anterior de modernismo era o ecletismo da construção de Belo Horizonte, das reformas urbanas do Rio de Janeiro e de Belém. Isso vai sendo considerado como de mau gosto, como expressão de um cosmopolitismo barato já que desconsiderava o antigo, o tradicional existente. A recusa ao ecletismo abre espaço para a criação de outra corrente que está se estruturando no início dos anos 1920, é o "neocoIonial" que, segundo Carlos Kessel (2002), foi o estilo apresentado como moderno na Semana de Arte moderna de 1922, em São Paulo.

Na coluna dominical do "Diário de Pernambuco", GF critica a descaracterização da cidade, a destruição do velho Recife. Prédios, móveis e até nomes de ruas são expressões vivas de uma tradição cultural, diz ele, assim como o próprio paladar. Critica a imitação cega a um modelo francês de arquitetura e de urbanismo. Defende a adesão mais seletiva à modernidade.

Essa pregação regionalista nas colunas do DP, a organização do volume comemorativo do centenário do DP, intitulado Livro do Nordeste (1925), a criação do Centro Regionalista do Nordeste (1924), a realização do Primeiro Congresso Regionalista do Nordeste, realizado em fevereiro de 1926, são eventos, esforços, iniciativas que vão definindo um regionalismo que, segundo GF, seria uma afirmação da diversidade dentro da unidade. 
Após o Primeiro Congresso Regionalista, em 1926, GF parte para os Estados Unidos, como delegado do DP, ao Congresso Pan-Americano de Jornalistas. Antes, passa por Salvador e pelo Rio de Janeiro, conhecendo, pela primeira vez, a capital federal onde encontra figuras intelectuais e participa da boemia carioca. Esse encontro é mencionado no livro de Hermano Viana, O mistério do samba (1995).

Assim, acompanhando a biografia de GF, encontramos o cronista dos "artigos numerados" do "Diário de Pernambuco", o organizador do Livro do Nordeste (1925), o promotor do Congresso Regionalista do Nordeste (1926). Em 1927, o autor encerra sua participação no DP para assumir o posto de Secretário de Governo de Estácio Coimbra e se torna editor do jornal "A Província" (a partir de 1928), mostrando como Freyre vai elaborando uma nova cartografia histórica e cultural da cidade (LIRA, 2005).

Freyre narra em diversos textos suas experiências pessoais, vendo, observando e registrando suas impressões, suas sensações de viajante. Sua viagem à Europa, entre 1922 e 1923, causa estranhamento, disponibilidade, encantamento; elementos centrais da formação intelectual e moral do grand tour (SALGUEIRO, 2003). Suas viagens pelo Brasil, ao Rio e São Paulo, em 1926, também fazem parte dessa formação, que passa pelo flâneur, pelo etnográfico, chegando ao cicerone e ao anfitrião.

O Guia prático, sentimental e histórico de Recife, publicado em 1934, segundo Lira, abole a "norma turística" ao introduzir evocação, intuição, imaginação para acessar o "caráter" da cidade e faz suscitar um novo modo de ver, uma nova perspectiva da cidade.

Guillermo Giucci (2000) vai garimpar na coluna dominical que Gilberto Freyre manda, ainda dos Estados Unidos, para o jornal "Diário de Pernambuco", antes de 1923. Registra que, em uma crônica, Freyre faz menção à morte de Fritz Baedeker, indica a insuficiência dos roteiros turísticos disponíveis e se pergunta se é possível libertar-se da "carinhosa tirania do Baedeker e da Cook". E quem são esses? A curiosidade nos leva a saber que Baedeker é nome de guia famoso, cuja família inicia, nos anos 1830, a publicação dos primeiros livros sobre viagem na Alemanha. Será um descendente, Fritz, que torna o Baedeker o top de linha dos guias de viagem em língua inglesa, em 1889. Thomas Cook, americano igualmente famoso do circuito de viagens e dos guias, ingressa no mercado europeu de viagem ao mesmo momento que Baedeker entra no circuito de guia de viagem dos Estados Unidos e Canadá. Em torno de 1914, Baedeker já se tornara sinônimo de guia de viagem. É, assim, frente a esses nomes "sagrados" na produção de guias, que GF vai se posicionar dizendo que há outras maneiras, outros modos de viajar. 
É também em uma das crônicas para o "Diário de Pernambuco" que Freyre assinala o "vitalismo" que encontrou em Nova York. Após sua viagem à Salvador, escreve artigo comentando traços da cidade para o jornal, o que também estará registrado no poema "Bahia de todos os Santos e de quase todos os pecados" (1926). Falaremos mais sobre o poema adiante. O Rio de Janeiro, segundo a leitura de Guicci sobre a visão de cidade em GF, não aparece referido em suas crônicas como nenhuma maravilha. A cidade não the oferece a sensação de concentração urbana, aparecendo antes como unida à natureza, vegetação, beleza morena, praia.

As viagens, assim como o olhar sobre as cidades, ganham tons particulares que dependem também dos amigos que fazem o papel de mediadores ou de cicerones. Silvana Moreli (2008), no texto já mencionado, destaca e recupera as trajetórias de GF e de Manuel Bandeira. Examinando a correspondência entre os dois, ela vai mostrar, entre outros aspectos, o apoio de Bandeira às constantes idas de Gilberto Freyre ao Rio de Janeiro.

Será também Manuel Bandeira quem vai dizer que as palavras 'província', 'provinciano', 'provincianismo' eram empregadas como referência às 'limitações do meio pequeno' e que foi Gilberto Freyre aquele capaz de moldar um novo sentimento de província que defende as especificidades da cultura local. Segundo a autora, a partir da trajetória de Freyre e de Bandeira,

(...) haveria a moldagem de um modo diferencial de ser moderno, que procura conciliar a abertura para o novo, como a descentralização de temas e de gêneros, junto a uma sensibilidade não de todo desatada das velhas formas e, de algum modo, enraizada na própria experiência subjetiva e coletiva. (MORELI, 2008, p. 2)

Moreli destaca, principalmente, a aproximação entre esses dois intelectuais no jornal "A Província", no período que vai de agosto de 1928 a outubro de 1930, e mostra a relevância de seu papel no cenário cultural do Recife dos anos 20, ao conseguir reunir um corpo de colaboradores capaz de renovar o formato da informação, o diálogo com a vanguarda modernista do Rio e de São Paulo. Nas suas páginas 'provincianizar-se' não envolve nenhuma contradição entre ser moderno e ser regional. O grupo em torno de "A Província" é composto por José Américo de Almeida, José Lins do Rego, Jorge de Lima, Mário Sette, Aníbal Fernandes, Sylvio Rabello, Luís Cedro, José Maria Bello, Júlio Bello, Ascenso Ferreira, Olívio Montenegro, Manuel Bandeira, Prudente de Moraes Neto (sob pseudônimo de Pedro Dantas), Ribeiro Couto, entre outros (2008, p. 8).

No jornal "A Província", não há fronteiras entre moda, política, música, economia, arquitetura, vida literária, divulgação de novos livros. Ao lado de artigos sobre temas nordestinos - rendas, vida de santos, festas populares, engenhos, 
os rios do Recife, cangaceiros, maracatu, carnaval, tipos populares que estão desaparecendo, pescaria, mocambos, nome de ruas, sertanejos, azulejos, estilo colonial, arte marajoara, patrimônio artístico de Pernambuco - publicava também novidades de outras partes do Brasil e do mundo em crônicas que falavam de Lasar Segall, Anna Pavlova, Carlito, Conrad, Proust, Pirandello, Le Corbusier, além de apresentar artigos sobre o telefone, esporte, arquitetura moderna, arqueologia mexicana e cinema. Os temas mais cosmopolitas eram assinados por Bandeira, enquanto os mais regionais eram assinados por Freyre, adotando diferentes pseudônimos. O jornal mantinha certo equilíbrio entre o enfoque cosmopolita e o tradicional. E, continua a autora, "a modernização gráfica também foi um diferencial do jornal, que pôde contar com a colaboração dos pintores Manoel Bandeira e Luiz Jardim" (p. 9).

"A Província" é um jornal que pode ser citado como um caso exemplar de "provincianização modernizadora' do Recife, provincianização identificada com o ritmo e os problemas da vida local e, ao mesmo tempo, abertura para o mundo. Giucci e Larreta (2007, p. 336) também acentuam esse provincianismo modernizante do jornal, capaz de conciliar província e cosmópolis, local e universal, tradição e vanguarda.

\section{Poemas e Guias}

Freyre e Bandeira, cada um a seu modo, praticaram gêneros como guias de cidades, crônicas e poemas, ainda que GF seja reconhecido principalmente, como antropólogo e Bandeira seja, indiscutivelmente, o poeta.

As estreitas relações entre GF e MB são também comentadas por Marisa Veloso, "eram amigos-irmãos ou melhor, enfaticamente amigos verdadeiros, onde a phillia, ou seja, a afinidade espalha-se como fonte em todas as dimensões da convivência" (2000, p. 364). Entre as afinidades está o gosto pelas experiências brasileiras e o apreço pela tradição. Os dois autores escreveram poemas sobre cidades e guias de cidades: Bandeira escreveu o poema "Evocação do Recife" e O guia de Ouro Preto; GF escreveu o poema "Bahia de Todos os Santos e de quase todos os pecados" e o Guia da cidade do Recife.

E, continua a autora, as afinidades entre o poema "Evocação do Recife" (1925) de Manuel Bandeira e o Guia prático, histórico e sentimental da cidade do Recife (1934) de GF estão exatamente na valorização da tradição, dos rastros do tempo, das formas de sociabilidade e intimidade que se deixam evocar pelos sentidos, pelo cheiro, pela cor, pelas relações sexuais. É a capacidade de apreender a experiência através dos sentidos o que mais une os dois autores.

É também possível sinalizar as afinidades entre o poema "Bahia de todos os 
Santos e de quase todos os pecados" de Gilberto Freyre e o Guia de Ouro Preto (1937), escrito por Manuel Bandeira.

Vamos, aqui, explorar o poema "Bahia de todos os santos e de quase todos os pecados"2 (1926) e apontar tópicos e questões que vão aparecer mais tarde no Guia da cidade do Recife.

Bahia de Todos os Santos (e de quase todos os pecados)

2. http://bvfgf.org. br/portugues/obra/ poesias/bahia.htm (consultado em 06/08/2008)

Casa trepadas umas por cima das outras

Casas, sobrados, igrejas, como gente se espremendo pra sair num retrato de revista ou jornal

(vaidade das vaidades! Diz o Eclesiastes)

Igrejas gordas (as de Pernambuco são mais magras)

Toda a Bahia é uma maternal cidade gorda

Como se dos ventres empinados dos seus montes

Dos quais saíram tantas cidades do Brasil

Inda outras estivessem para sair

Ar mole oleoso

Cheiro de comida

Cheiro de incenso

Cheiro de mulata

Bafos quentes de sacristias e cozinhas

Panelas fervendo

Temperos ardendo

O Santíssimo Sacramento se elevando

Mulheres parindo

Cheiro de alfazema

Remédios contra sífilis

Letreiros como este:

Louvado seja Nosso Senhor Jesus Cristo

(Para sempre! Amém)

Automóveis a 30 \$ a hora

$E$ um ford todo osso sobe qualquer ladeira

Saltando pulando tilintando

Pra depois escorrer sobre o asfalto novo

Que branqueja como dentadura postiça em terra encarnada

(a terra encarnada de 1500)

Gente da Bahia! Preta, parda, roxa, morena

Cor dos bons jacarandás de engenho do Brasil

(madeira que cupim não rói)

Sem rostos cor de fiambre

Nem corpos cor de peru frito

Bahia de cores quentes, carnes morenas, gostos picantes 
Eu detesto teus oradores, Bahia de Todos os Santos

Teus ruisbarbosas, teus otaviosmangabeiras

Mas gosto de tuas iaiás, tuas mulatas, teus angus

Tabuleiros, flor de papel, candeeirinhos,

Tudo à sombra das tuas igrejas

Todas cheias de anjinhos bochechudos

Sãojoões sãojosés meninozinhosdeus

E com senhoras gordas se confessando a frades mais magros do que eu

O padre reprimido que há em mim

Se exalta diante de ti Bahia

E perdoa tuas superstições

Teu comércio de medidas de Nossa Senhora e de Nossossenhores do Bon-

fim

E vê no ventre dos teus montes e das tuas mulheres

Conservadores da fé em vez entregue aos santos

Multiplicadores de cidades cristãs e de criaturas de Deus

Bahia de Todos os Santos

Salvador

São Salvador

Bahia

Negras velhas da Bahia

Vendendo mingau angu acarajé

Negras velhas de xale encarnado

Peitos caídos

Mães das mulatas mais belas dos Brasil

Mulatas de gordo peito em bico como pra dar de mamar a todos os meninos do Brasil.

Mulatas de mãos de anjos

Mãos agradando ioiôs

Criando grandes sinhôs quase aos do Império

Penteando iaiás

Dando cafuné nas sinhás

Enfeitando tabuleiros cabelos santos anjos

Lavando o chão de Nosso Senhor do Bonfim

Pés dançando nus nas chinelas sem meia

Cabeções enfeitados de rendas

Estrelas marinhas de prata

Tetéias de ouro

Balangandãs

Presente de português

Óleo de coco

Azeite-de-dendê 
Bahia

Salvador

São Salvador

Todos os Santos

Tomé de Sousa

Tomes de Sousa

Padres, negros, caboclos

Mulatas quadrarunas octorunas

A Primeira Missa

Os malês

Índias nuas

Vergonhas raspadas

Candomblés santidades heresias sodomias

Quase todos os pecados

Ranger de camas-de-vento

Corpos ardendo suando de gozo

Todos os Santos

Missa das seis

Comunhão

Gênios de Sergipe

Bacharéis de pince-nez

Literatos que lêem Menotti Del Picchia e Mário Pinto Serpa

Mulatos de fala fina

Muleques

Capoeiras feiticeiras

Chapéus-do-chile

Rua Chile

Viva J. J. SEABRA morra J. J. SEABRA

Bahia

Salvador

São Salvador

Todos os Santos

Um dia voltarei com vagar ao teu seio moreno brasileiro

Às tuas igrejas onde pregou Vieira moreno hoje cheias de frades ruivos e bons

Aos teus tabuleiros escancarados em $\times$ (esse $x$ é o futuro do Brasil)

A tuas casas a teus sobrados cheirando a incenso comida alfazema cacau

Não estamos avaliando as qualidades literárias do poema. "Evocação do Recife" de Manuel Bandeira, segundo meu gosto, é infinitamente melhor, mas isso não vem ao caso. O poema "Bahia de Todos os Santos e de quase todos os pecados" fala das casas e ruas, das cenas do cotidiano, dos cheiros, das cores, dos rituais, 
dos letreiros, das personagens. Parece cena descrita ou pintada por um estrangeiro chegando pela primeira vez à cidade, ainda que Gilberto tenha um repertório de saberes que o torna íntimo do lugar. Ao descrever, Gilberto vai dando sinais positivos e negativos àquilo que apresenta. Esse poema pode também ser considerado como uma das primeiras manifestações contra o bacharelismo, ao mesmo tempo reforça um imaginário sobre a mulata, que terá longa vida e que teve, como representante maior, Jorge Amado, como no trecho:

Eu detesto teus oradores, Bahia de Todos os Santos

Teus ruisbarbosas, teus otaviosmangabeiras

Mas gosto das tuas iaiás, tuas mulatas, teus angus

As relações de Gilberto com a Bahia já receberam atenção com a publicação do livro Na Bahia, de 1943. Na apresentação ao livro, intitulada Bahia e baianos, Edson Nery da Fonseca nos informa que o livro reúne artigos dispersos em jornais, revistas e outras obras que falam exatamente das suas relações com a Bahia. Relembra Nery da Fonseca, que a visita à Bahia, em 1926, produziu também um artigo, publicado no "Diário de Pernambuco", "Bahia à tarde" que, da mesma forma que o poema, apresenta apelos visuais, olfativos e táteis. Em 1930, Gilberto volta a Salvador, acompanhando a fuga do governador Estácio Coimbra então deposto pela Revolução. Essa estada permitiu, segundo ele próprio, "conhecer com todo o vagar não só as coleções do Museu Afro-Baiano Nina Rodrigues e a arte do trajo das negras quituteiras e a decoração dos seus bobos e tabuleiros como certos encantos mais íntimos da cozinha e da doçaria baiana que escapam aos simples turistas".

No prefácio da primeira edição de Casa Grande \& Senzala, Gilberto vai agradecer tanto a figuras importantes das famílias da Bahia, quanto a informantes das particularidades da cozinha. Diz ele: "Foi a Bahia que nos deu alguns dos maiores estadistas e diplomatas do Império; e os pratos mais saborosos da cozinha brasileira em lugar nenhum se preparam tão bem como as velhas casas de Salvador e do Recôncavo".

Gilberto Freyre já dissera, recorda Edson Ney:

Triste do brasileiro que não tenha dentro de si algumas coisas de baiano. E não só da urbanidade baiana; não só de polidez baiana; não só de gentileza baiana; não só de civilidade; não só do bom gosto baiano; não só de religiosidade baiana; não só de ternura baiana; não só de civismo baiano; não só de inteligência baiana. Mas também alguma coisa da malícia, de "humor", de gaiatice compensadora dos excessos de dignidade, de solenidade e da própria elegância.

Gilberto chegou a anunciar, em 1940, que escreveria um guia prático, histórico 
e sentimental da Cidade do Salvador, à semelhança do realizado para Recife e do escrito para Olinda, mas desistiu quando viu guia similar realizado por seu amigo Jorge Amado.

Essa conexão entre Gilberto Freyre e os baianos, entre Recife e Salvador vai sendo tecida por diversas figuras da intelectualidade, da literatura nordestina dos anos 1930 e 1940.

No prefácio de Região e Tradição, Gilberto menciona os jovens José e Clarival Valladares como expressões da baianidade. A conexão é mencionada em diferentes fontes. Recife e Gilberto Freyre exercem influência para todos os jovens baianos e nordestinos que vão fazer curso de direito na capital pernambucana. É também notável a reprodução do gênero "guia de cidades" como o texto de Jorge Amado, Bahia de Todos os Santos; guia das ruas e dos mistérios da Cidade de Salvador (1945); José Valladares, Bêabá da Bahia; guia turístico (1951).

Voltando ao poema "Bahia de Todos os Santos", como já dissemos, ele é resultado da primeira viagem feita por Gilberto, em 1926, a Salvador, ao Rio de Janeiro e a São Paulo. Ao regressar ao Recife e depois de viajar aos Estados Unidos, como delegado do "Diário de Pernambuco", ao Congresso Pan-americano de Jornalistas, Gilberto assume o cargo político de chefe de gabinete do governo de Estácio Coimbra. Nesse governo, a educação foi entregue a Antônio Carneiro Leão e a saúde pública foi ocupada por seu primo Ulysses Pernambuco. A partir de 1928, como também já mencionamos, Gilberto passou a dirigir o jornal "A Província" e a dar aulas de Sociologia na Escola Normal do Estado de Pernambuco.

Teria sido por sua sugestão que Estácio Coimbra criou, em 1928, a Inspetoria de Monumentos Nacionais do Estado de Pernambuco e o Museu de Artes Retrospectivas (CHAGAS, 2003). A Inspetoria não teve continuidade nos anos 1930 e o Museu foi desativado em 1933 e reinaugurado em 1940, com o nome de Museu do Estado.

Algumas informações de sua trajetória, alguns trechos de seus escritos estão presentes como pegadas no Guia da cidade do Recife. Vejamos.

\section{Gilberto Freyre e o guia do Recife}

Vamos aqui relacionar o movimento regionalista com a visão da cidade, tomando como fonte principal o livro de Gilberto Freyre, Guia prático, histórico e sentimental da cidade do Recife, cuja primeira edição é de 1934.

Ao se ler o Guia do Recife de GF, entende-se melhor ter esse livro o título "Guia prático, histórico e sentimental". Gostaria de ter conhecido essa obra antes de 
visitar a cidade, ou melhor, quero voltar à cidade do Recife incorporando o olhar de GF.

O Guia teve sua primeira edição em 1934, com tiragem de 105 exemplares e desenhos coloridos à mão por Luís Jardim e foi impresso nas oficinas gráficas de The Propagandist, de Maurício Gomes Freire. Essa edição deve ser uma obra de arte e é peça de bibliófilos. Tal tradição de produção de livros de qualidade técnica e artística se fará presente, anos mais tarde, em O Gráfico Amador. O Guia teve segunda e quarta edições publicadas em 1942 e 1968, pela editora José Olympio, e, por fim, a quinta edição sai em 2007, pela Global Editora. Estamos fazendo uso dessa edição.

Não tinha prestado muita atenção a essas informações presentes na quinta edição, até me defrontar, no texto, com referências a eventos históricos acontecidos em datas posteriores aos anos 1930. Pode-se concluir, assim, que este Guia foi revisto por GF em suas novas edições, pelo menos até sua morte em 1987.

Valem os exemplos: ao valorizar grupos de teatro amador do Recife, GF menciona o de Cavalcanti Borges, o de Ariano Suassuna e o de Valdemar de Oliveira. Como esses grupos não existiam nos anos 30, fiquei atenta à questão. Freyre também menciona a Universidade Federal de Pernambuco, a televisão do Jornal do Comércio e a dos Associados. Cita dados da população pernambucana, em 1950. Menciona a Sudene (que foi criada em 1959). Ao comentar os visitantes ilustres, na residência de Apipupos, GF menciona Roberto Rossellini, John Dos Passos e políticos brasileiros como Jânio Quadros, Negrão de Lima, Carlos Lacerda e também o "atual Presidente da República, Marechal Costa e Silva" (p. 149). Os estudiosos de GF assinalaram a dificuldade de analisar seus textos, já que o autor os modifica cada vez que são publicados. Os textos oferecem camadas arqueológicas a serem descascadas...

O Guia apresenta oito capítulos (sem título) cada um deles contendo cerca de oito textos, cujo tamanho varia de uma a cinco páginas. A narrativa não obedece linearidade no tempo ou no espaço, embora cada capítulo apresente temas próximos. O livro parece apresentar a cidade tanto aos seus visitantes quanto aos seus moradores. Logo no início do Guia, GF se dirige ao viajante, ao turista, começa falando do "caráter" da cidade. Ela, a cidade, não se apresenta "escancarada à sua admiração, à espera dos primeiros olhos gulosos de pitoresco e de cor" (p. 23). Compara com o Rio de Janeiro e com a Bahia (Salvador), onde as igrejas são mais "gordas", as casas trepadas umas sobre as outras parecendo "grupos de gente se espremendo pra sair num retrato de revista" (p. 23). Foi assim que já fizera referência a Salvador no poema "Bahia de todos os Santos e de quase todos os pecados", em 1926: 
Bahia de Todos os Santos (e de quase todos os pecados)

Casas trepadas umas por cima das outras

Casa, sobrados, igrejas, como gente se espremendo pra sair num retrato de revista ou jornal

Recife, ao contrário, tem "o recato quase mourisco", sem saliências nem relevos. A cidade se deixa conquistar aos poucos, "prefere namorados sentimentais a admiradores imediatos". Certamente ele, GF, é um deles. Outros são mencionados ao longo do Guia. Joaquim Nabuco é outro deles e é mencionado muitas vezes ao longo dos capítulos do guia. Muitos viajantes, principalmente estrangeiros, também tornaram-se namorados da cidade.

A cidade tem mencionada sua especificidade. Esta é assinalada nas frases "pela primeira vez" tal ou qual evento, instituição ou feito teve ali lugar. Foi ali que existiu o primeiro observatório astronômico na América, o primeiro jardim zoológico, "o primeiro centro de cultura israelita na América, a primeira assembléia política". Para além desse pioneirismo do tempo dos holandeses, outros são mencionados. O Recife foi o primeiro ponto do Brasil a ser atingido pelos aviadores portugueses Gago Coutinho e Sacadora Cabral; foi a primeira cidade brasileira onde tocou o Zeppelin em sua viagem de inauguração da linha EuropaAmérica do Sul. No Recife se reuniu, por algum tempo, a população mais heterogênea do continente, gente das mais diversas procedências, credos, culturas ali se misturou. Cita, também, o Recife das revoluções, dos crimes, das assombrações - todo esse Recife que não consta dos livros que os turistas leem, os guias.

Recife é então apresentada como cidade cosmopolita que recebeu influência do Oriente, da Europa, dos Estados Unidos. "Foi burgo holandês, foi uma das cidades mais afrancesadas do Brasil assim como uma das mais anglicizadas". O germanismo se fez presente no mundo jurídico, filosófico e das letras, no tempo de Tobias Barreto. E nos lembra a presença da base americana, durante a Segunda Guerra Mundial.

Mesmo reconhecendo ser São Paulo a cidade mais cosmopolita do país, Gilberto observa que Recife tem muitos estrangeiros entre sua população. E vai mencionando a contribuição deles para os "caboclos da terra". Além de listar as casas, as escolas e seus educadores estrangeiros, GF apresenta demandas ou carências: a falta de um bom restaurante alemão, assim como de um francês.

Depois dos traços gerais do "caráter" do Recife, o autor fala dos traços climáticos da cidade. É verão quase o ano inteiro, há apenas duas estações: a seca e a de chuvas; não há furacões, nem tempestades. O conde Afonso Celso, autor do famoso Por que me ufano do meu país, ficaria feliz ao ler este Guia!

Junto aos atributos da natureza tropical, agrega outras queixas. A falta de um 
mercado de flores na cidade, onde o turista possa ver a riqueza e variedade da vegetação e da nossa fauna. Isso aconteceu no "bom tempo de Nassau" (p. 28), que mandou fazer um parque e um jardim zoológico. É preciso destacar que todas as menções ao tempo dos holandeses e de Nassau são positivas.

“Na República, porém, não se sabe por que estranho sentido de arte ou de higiene tropical, os prefeitos do Recife deram para perseguir as árvores como quem persegue inimigos" (p. 28). A velha tradição de preservar, valorizar as árvores originais vem sendo restaurada pela influência do Centro Regionalista do Nordeste, que teve ação sobre a vida da região e não se limitou a "fazer literatura" (p. 29). Hoje, volta-se a amar as árvores. A Praça de Casa-Forte, obra do mestre Roberto Burle Marx, e o Parque de Dois Irmãos são exemplos maiores. Observa que a arborização inteligente é necessária para corrigir o excesso de claridade e de sol.

Há, assim, uma certa regularidade na forma como Freyre elabora seu guia da cidade. Primeiro, ele menciona algum traço específico e, de preferência, positivo, ou que pode ser lido como positivo. A seguir, ele aponta momentos históricos quando isso existiu ou foi criado. Aponta, igualmente, como não vem sendo mantido ou cuidado como deveria ser. Assim, registra carências que podem ser contornadas ou demandas apresentadas como de interesse coletivo. Seu olhar treinado em suas viagens fora do país permite identificar as carências e possibilidades.

Para falar da cidade e de seus "namorados", GF fala de seus grandes nomes. Joaquim Nabuco, ainda que muito viajado, "nunca se desprendeu do seu Recife, da sua Mauricéia, da sua Veneza tropical" (p. 35). Nabuco nunca se impressionou com o mundo jurídico que frequentou na Faculdade de Direito do Recife. "Seu sentido dos problemas brasileiros já era o histórico-sociológico, tão característico dos intelectuais autenticamente recifenses" (p. 35). Ao falar do Recife, de Pernambuco, o autor vai criando seus ancestrais, vai escolhendo aqueles que devem ser lembrados como antecessores. Não por acaso, o então deputado federal Gilberto Freyre será autor do projeto de lei que vai criar o Instituto Joaquim Nabuco de Pesquisas Sociais, em 1949, transformado em Fundação Joaquim Nabuco, em 1980.

Comenta a campanha abolicionista de Nabuco, vencida no Teatro Santa Isabel, e as críticas desferidas a ele, Quincas, o Belo. "Havia no Recife quem o acusasse de pedante, de adamado, de taful. (...) Quem o achasse afrancesado, inglesado, estrangeirado" (p. 36). Segundo Freyre, grandes e ilustres pernambucanos foram atacados por "arrivistas intelectuais e sociais", vindos de outras províncias menores que, ao chegarem ao Recife, cometiam esses "pecados de mocidade". O historiador e diplomata Oliveira Lima, o Barão do Rio Branco, o poeta Manuel 
Bandeira estão entre os recifenses ou pernambucanos ilustres mencionados no Guia.

Freyre vai, por assim dizer, perambulando pela cidade e por temas que lhe são caros. Passeia olhando as casas, os prédios, lendo a história que a arquitetura nos conta. Faz o mesmo em relação às festas e manifestações populares que acontecem nas ruas e praças.

Os sinos das igrejas com sua linguagem, ainda estão lá, já que os "progressistas" ainda não se lembraram de recolhê-los ao Museu do Estado, ironiza o autor. Valoriza os nomes das ruas e defende o movimento a favor da conservação dos nomes antigos, que recebeu o apoio do poeta Manuel Bandeira no seu poema "Evocação do Recife", escrito a pedido de outro recifense (o próprio GF).

A conservação dos nomes das ruas, das árvores tradicionais, da arborização das ruas e praças, a defesa da doçaria tradicional, dos móveis de jacarandá, da conservação dos jogos e brinquedos tradicionais constituem itens da plataforma do Centro Regional do Nordeste, criado em 1924. Ressalta que o Centro, ao criar a Semana da Árvore, marcou o início do respeito pela árvore. Isso se deve ao inquérito realizado por estudantes de sociologia, orientado pelo primeiro professor moderno da matéria, não só no Recife como também no Brasil (o próprio GF), (p. 47).

Nomeia restaurantes e mercados a serem visitados pelo turista. $\mathrm{O}$ autor introduz o comentário: "quem garatuja este arremedo guia (guia que sendo sentimental é também o seu tanto histórico e à vezes dá-se o luxo de ser prático)" (p. 55). Menciona a fartura de frutas tropicais da cidade, cita de sorvetes a passarinhos. Nos mercados, estão à venda ervas, potes, folhetos de "histórias regionais". "Às vezes lá aparecem cantadores com sua viola; ou um cego-cantador; ou algum novo Ascenso Ferreira a recitar para os recifenses versos populares da gente do interior" (p. 50). Recomenda, também, a visita a alguma sede de maracatu e fazer amizade com um dos filhos do babalorixá Pai Adão.

Os vendedores estão presentes nas ruas e feiras com seus objetos, redes, farinha, produtos de simplicidade primitiva. Muitos deles já velhos, "magricelas vigorosos que lembram o tipo sertanejo exaltado por Euclides da Cunha" (p. 52).

As frutas, a negra da tapioca, os vendedores mencionados por Freyre são apresentados por desenhos de Luis Jardim, espalhados ao longo do livro.

Fala dos pregões que não se ouvem, seja porque os artigos já desapareceram, seja porque as buzinas dos automóveis e os alto-falantes os abafaram. Transcreve pregões desaparecidos e outros vivos, reproduz músicas que alegram os carnavais, marchas e frevos do Mestre Capiba e de outros compositores regionais. 
3. Interessante notar que GF escreve texto intitulado "narcisismo gaúcho", em 1940 (NEDEL, 2007).

4. Essa figura, creio, é o pai de José Mariano Filho, liderança do movimento neocolonial no Rio de Janeiro, e do poeta Olegário Mariano (KESSEL, 2008, p. 107-114)
Os "tipos populares" que conheceu no tempo da República Velha, tipos pitorescos do Recife, são cada vez menos presentes, mas ainda estão nos últimos maracatus, como o Maracatu de Dona Santa.

Se tudo isso vai, como canto da sereia, encantando o leitor, há uma outra marca que causa estranhamento e, diria, mesmo desagrada. Ele não perde uma ocasião para se autoelogiar. Esse traço de sua persona, também já mencionado pelos estudiosos, aparece neste Guia de forma, diria mesmo, de forma irritante $\mathrm{e}^{3}$. Como compreender isso? A "promoção de sua personalidade à posição de único e verdadeiro centro criador de sua reflexão", é mencionada por Ricardo Benzaquen de Araújo (1997) ao analisar as diversas características (originalidade, precocidade e sistematicidade), que aparecem na construção da noção de gênio que Gilberto Freyre vai apresentando ao longo de sua obra. Sua genialidade cobra uma fidelidade e um amor sem limites, ou seja, exige que seus leitores e admiradores o apreciem sem considerar seus vícios. Um de seus "pecados" confesso é a vaidade que, "ao contrário do orgulho, é uma forma de afirmação da própria superioridade que necessita - desesperadamente - da aprovação dos outros, dos inferiores, do mais comum dos mortais, para que consiga se sustentar" (p. 260).

Continuando a percorrer as páginas do Guia encontramos, entre as figuras do Recife antigo, José Mariano Carneiro da Cunha, aristocrata de engenho que, no Recife, se torna democrata e mesmo populista ao se tornar amigo até de capoeiras (p. 58)

Retoma Nabuco e sua afirmação de que foi no Teatro Santa Isabel que ganhou a batalha da Abolição. Teatro construído pelo engenheiro francês L. L. Vauthier, na primeira metade do século XIX. Vauthier que veio a Pernambuco convidado pelo presidente da Província, Francisco do Rego Barros, depois Barão da Boa Vista. É dele também o traçado do cemitério de Santo Amaro, onde se destacam obras de arte do século XIX.

O amor à luz vinda do sol, "às vezes um tanto tirânica pelo próprio excesso da sua pureza tropical" (p. 67) é complementada pela luz elétrica de Paulo Afonso. Amor ao ar, à temperança, à doçura das manhãs e dos fins de tarde se faz presente na poesia dos recifenses, como Mauro Mota, Manuel Bandeira, Joaquim Cardoso, Carlos Pena, Carlos Moreira, Ascenso Ferreira, entre outros, além de João Cabral de Melo Neto, que vem se tornando o poeta por excelência do Capibaribe.

Vai mencionar estrangeiros que escreveram sobre o clima tropical e a liberdade de se viver ao ar livre o ano inteiro. Liga o trópico ao ideal, outrora grego e hoje ibero-americano, de liberdade pessoal. Viver ao ar livre, discutir política, 
conversar sobre literatura, opereta ou corrida de cavalos, fazer transações comerciais, é hábito do recifense desde o século XIX. "Conversando e às vezes praguejando" (p. 68), pragas estas que os papagaios aprendiam com facilidade. Fala também do hábito dos homens cuspirem em qualquer lugar, emporcalhando a cidade e até de defecarem ao pé das pontes da cidade.

O médico Aluísio Bezerra Coutinho e os engenheiros Lauro Borba e Antonio Baltar são mencionados positivamente, já que têm se preocupado com os problemas da cidade. Lembra, em primeiro lugar, de Saturnino de Brito, aquele que associou água com a cidade e construiu as represas de Gurjaú, que garantem água ao Recife. Estes se opõem aos maus urbanistas recifenses que têm revelado fúria contra as águas, "fobia a essas águas", haverá quem queira aterrar primeiro o Beberibe e depois o Capiberibe.

O turista, mesmo sem guia, vai descobrir os rios e suas pontes e sentir as ilhas e quase-ilhas que compõem a cidade. O Capiberibe, antes de passar pelo Palácio do Governo, conhecido como Campo das Princesas - construído quase no mesmo lugar que, no século XVII, Nassau levantou seu castelo - atravessa boa parte da cidade.

"Da Rua da Aurora já se disse que é uma das ruas mais caracteristicamente recifenses: talvez a mais recifense. É de todas a mais cortejada pelo Capiberibe. Seu nome é poético" (p. 71). Na Aurora estão a Prefeitura, o Colégio - outrora Ginásio Pernambucano, onde ilustres brasileiros, entre eles Epitácio Pessoa, fizeram seus estudos secundários. Do rio também se avista o Teatro Santa Isabel.

As jangadas e seus jangadeiros fazem parte dessa cidade levantada entre a água do mar e a mata tropical, e essa situação se expressa nos valores culturais. 0 porto é parte disso tudo, ainda que precise de drenagem, da atenção do governo federal.

As águas do Capibaribe, do Beberibe, do mar, de açudes, dos mangues, dos banhos de rio de ontem e dos banhos de mar de hoje, mar com sua sucessão de piscinas de águas verdes e mornas, entre os arrecifes e a praia, faz ser natural os recifenses adorarem a água. Ponte, botes ou canoas são instituições recifenses ${ }^{5}$.

"Demorando no Recife, o turista não deixe de ir a Olinda. É a mãe do Recife. Podendo vá também a Igaraçu, que é a avó" (p. 89). De Olinda vale ver: o antigo Colégio dos Jesuítas; o convento de São Francisco; o Mosteiro de São Bento entre outros. Recomenda também: "Não deixe de subir até a Misericórdia onde se tem uma das melhores vistas de Recife".

Da vida religiosa fala da presença do protestantismo, desde os tempos coloniais, com os holandeses e calvinistas franceses, e dos seminários presbiteriano
5. Nesse Guia, Freyre não menciona as "casas de banho" construídas à beira dos rios, experiência singular no Brasil. 
6. Freyre monta uma hierarquia do estilo barroco: primeiro as igrejas europeias, depois as do México e do Peru; as de Salvador não são sequer mencionadas. e batista existente na cidade. Cita várias igrejas protestantes e o cemitério dos ingleses, além de duas sinagogas. Mas reconhece que a maior presença é mesmo da religião católica com suas festas das padroeiras e da Semana Santa. Suas procissões onde as irmandades e confrarias se apresentam.

Havia também vários xangôs que hoje estão em decadência. "Os antigos eram verdadeiras religiões" (p. 99). Menciona bons terreiros que merecem ser visitados e suas festas. "O calendário das festas religiosas mais populares nos xangôs do Recife indica um sincretismo que vem passado a ser, (pelo declínio do catolicismo como religião mística) de assimilação de crenças e cultos católicos a favor de uma renascença católico-africana" (p. 101).

Igrejas e conventos merecem atenção e a menção a traços cotidianos, como a linguagem dos sinos, os enterros nas igrejas, os ex-votos.

Por outro lado, igrejas e conventos são exemplares do estilo barroco no Recife. O estilo barroco não comparece com nenhuma maravilha de arte religiosa, "nenhuma catedral que se compare, já não diremos às européias, mas às do México e do Peru" (p. 104)'.

As igrejas, como quase toda arquitetura colonial brasileira, são "encantos de espontaneidade". Ao descrever as igrejas, GF vai contando eventos históricos ali acontecidos, destacando os azulejos e jacarandás do coro, os painéis, a capelamor e seus retábulos. E esclarece: "Todo o primor de arquitetura que aqui se admira foi obra de frade" (p. 107). São muitos os croquis das igrejas que acompanham o texto.

Pontua essa avaliação registrando o que se perdeu em reformas recentes; o mau gosto das restaurações; os pedaços de altares, de arcos e de igrejas demolidas. "Felizmente, nos últimos trinta anos, acentuou-se entre nós a reação a favor do barroco; deixou-se de bulir nas igrejas velhas com a sem-cerimônia de outrora" (p. 146).

Fala também de Igrejas onde africanos iam dançar seus maracatus - restos das antigas organizações coloniais de reis do congo, ou reis que os escravos tinham o direito de eleger (p. 110). Recomenda ao turista ver um maracatu do Recife: Leão do Norte, Cabinda Nova, Pavão Dourado, Estrela Brilhante, Leão Coroado.

Os livros escritos pelos ingleses, principalmente diários e livros de viagem, são leitura fundamental para se fazer a história social do Recife. E, continua Freyre, aos ingleses se deve o serviço de esgoto, de gás, de eletricidade, de saneamento e de abastecimento de água, que foram por eles realizados ou iniciados. Depois dos holandeses e dos ingleses, são os franceses os mais ligados à história e à vida do Recife. Franceses foram vários engenheiros que contribuíram para 
o progresso do Recife, com ações no porto, na arquitetura, na higiene. Além do já mencionado Vauthier, construtor do Teatro Santa Isabel, fala de Fournié, que dirigiu as Obras Públicas, e de Béringer e Dombre, como realizadores de estudos científicos de interesse. Franceses eram os cabeleireiros e as modistas tornando afrancesada a sociedade recifense do século XIX, já que, durante o século XVII, era uma sociedade quase mourisca.

O texto corre como se estivéssemos conversando no alpendre da casa de Apipupos. Às vezes o autor se obriga a ser prático, com informações objetivas, mas que não constituem a principal mensagem do livro. Estas ficaram envelhecidas, permanecem como perenes seus comentários e observações significativas que expressam seu olhar sobre a cidade e seus costumes.

Os sobrados do Recife, os mais antigos, são do tipo magro, esguio, alto, de aspecto holandês ou flamengo. Novamente os relatos dos viajantes são acionados para atestar a paisagem incomum da cidade. A altura dos velhos sobrados não é fenômeno do século XIX já que, sabe-se que em meados do século XVII, havia casas muito altas, mesmo para a Europa e para as Américas. No Recife do século XVII, haveria assim "sobrevivência rara do gótico do Norte da Europa" (p. 154). A ideia é que, no Recife, proliferou uma verticalidade vinda da Europa mais precocemente burguesa e comercial, que se expressa na arquitetura da cidade e que depois se faz presente na Nova Amsterdã (p. 155). Pronto, Nova York descende do Recife!!!

Preza a integração entre arquitetura e meio nas antigas residências, com muito azulejo e escadarias nobres. Cita donos antigos e novos; as recepções acontecidas nos casarões; os parentescos de seus proprietários; as novas utilizações das antigas residências pelas sedes de clubes e outras atividades.

Lista os monumentos, as estátuas e bustos, as placas comemorativas e suas localizações. Os monumentos históricos e artísticos guardam o passado e o civismo do Recife.

Volta a falar do tempo dos holandeses. E anota: não existe busto ou estátua de Nassau no Recife, assim como não existe busto ou estátua de Vauthier. Estes são figuras heróicas do passado e explica, herói é o homem extraordinário pelas suas virtudes e audácias de realizador.

O Prefeito atual do Recife, Augusto Lucena, está sendo, para a metrópole do Nordeste, uma espécie de Pereira Passos: com as virtudes e os defeitos dos Pereiras Passos. Ativo e dinâmico, poderia juntar a essa virtude um maior amor às tradições recifenses. Seria então um prefeito quase perfeito. (p. 175) 
7. Vale lembrar que Percy Lau foi fundamental ao criar as figuras que passaram a representar os tipos regionais nos textos do IBGE e nos livros de geografia (DAOU, 2001).
Recomenda que o turista veja, no Museu do Estado, criado pelo governador Estácio Coimbra, as telas de Teles Júnior, paisagista que pintou as águas do Recife; os objetos da coleção do velho Baltar; as peças da coleção Brás Ribeiro e, no setor de arqueologia e etnografia, recomenda a coleção Carlos Estevão, pernambucano que foi, por algum tempo, diretor do Museu Goeldi, do Pará.

"O Recife é uma cidade de pintores. Mais de pintores, com certeza, do que de músicos ou de escultores ou de arquitetos. Talvez por causa da sua luz" (p. 187). De Franz Post, passando por Teles Júnior, chega aos pintores seus contemporâneos como Vicente e Joaquim do Rego Monteiro, Cícero Dias, Francisco Brennand (também ceramista), Luís Jardim, Lula Cardoso Ayres. Nos dias de hoje, Lula Cardoso é o pintor por excelência do Recife, como Mauro Mota é o poeta. Entre outros pintores cita o jovem Aloísio Magalhães. Entre desenhistas, menciona Manoel Bandeira (não confundir com o poeta) que ilustrou o Livro do Nordeste, comemorativo do $1^{\circ}$ Centenário do "Diário de Pernambuco", organizado por Freyre.

Entre outros nomes de pintores, desenhistas, fotógrafos, GF nos informa que: "de formação recifense é o desenhista brasileiro Percy Lau" , rival de M. Bandeira no desenho exato e na precisão do traço. No Recife viveu por algum tempo o paraibano Tomás Santa Rosa" (p. 189).

O Guia apresenta lista de nomes da literatura, ensaístas, advogados e engenheiros recifenses ilustres, sempre destacando a excepcionalidade deles. A vida cultural da cidade é enfatizada através da menção a grupos de teatro e fala também da construção em andamento de "Nova Jerusalém", em Fazenda Nova, interior do estado, um grande teatro ao ar livre para representar o drama da Paixão de Cristo (p. 222).

Não se pode esquecer, diz Freyre, que foi Estácio Coimbra quem fundou, no Recife, uma Inspetoria de Monumentos, antecipando no plano estadual o serviço federal criado por Vargas, em 1937. E não podemos esquecer, dizemos nós, que ele, GF, era o chefe de gabinete de Estácio Coimbra, ao mesmo tempo em que dirigia o jornal "A Província".

Os nomes mencionados, seja de pessoas, de lugares, de obras, como já foi dito, são apresentados como se fosse um exercício de livre associação. Gilberto escreve como se o guia fosse um livro de memória e não de história, no sentido que não respeita a linearidade da cronologia histórica. Assim, seu guia é basicamente um guia sentimental onde ele apela à sua memória, à sua vivência na cidade e, ao fazer isso, acaba transmitindo uma apaixonada, íntima, familiar versão sobre o Recife.

Ao comentar as casas do Recife, Gilberto Freyre fala, entre as bem situadas, 
dos mocambos que, transferidos dos lugares baixos e aterrados para os altos e secos, "chegam a ser, enquanto sua palha não envelhece e seu chão não se degrada, residências ideais para o trópico" (p. 149). Sabe que sofrem deterioração fácil e rápida, haja vista o material empregado em sua construção, mas, mesmo assim, os mucambos vão merecer a atenção do autor quando os considera a moradia "ecológica" do Recife, vai nomeá-los como a "casa primária" do Brasil.

Seu texto Mucambos do Nordeste: algumas notas sobre o tipo de casa popular mais primitivo do Nordeste do Brasil foi publicado, em 1937, pelo SPHAN, o que indica o encontro de trabalhos e de perspectiva entre Gilberto e Rodrigo Melo Franco de Andrade. Rodrigo escreve a introdução de Mucambos e registra o descaso com a arquitetura popular, coisa que a publicação do texto de Gilberto procura sanar. A relação entre essas duas figuras aparece também em cartas de Rodrigo a Gilberto, pedindo orientação, solicitando trabalhos de levantamento, autorizando a contratação de auxiliares, o pagamento de serviços e o reembolso de despesas (RIBEIRO, 2008, p. 58).

Ainda sobre os mucambos cabe registrar que, para além da sua precariedade, sua coberta de palha e paredes de pau-a-pique, eles são adaptados às carências daqueles que o criam. Nesse sentido, segundo Gilberto Freyre, eles são autênticos.

Nesse mesmo tempo, os mucambos do Recife tinham no interventor Agamenon Magalhães o mais ferrenho opositor. Para este, a precariedade de sua cobertura de latão ou zinco, a localização em áreas impróprias (os mangues) faziam parte do discurso para caracterizar aquelas moradias como o que mais "degenera" a cidade do Recife.

O Guia prático... (1934), Olinda: $2^{\circ}$ guia prático, histórico e sentimental (1939) e o guia não declarado Apipupos: que há num nome? (1983) são variações sobre um tema: valorização da casa, dos nomes de rios e ruas, de caminhos, de bairros, de paisagens, de tipos humanos que constituem um complexo cultural e conformam uma civilização.

Vale registrar que a moradia onde Gilberto Freyre viveu, a partir de 1940, e guardou objetos que expressavam sua vida, suas viagens e seu gosto, tornou-se uma "casa museu". A casa de José Mariano, nome importante do movimento neocolonial, contra o qual se opuseram os modernos, situada à Rua Jardim Botânico, chamada Solar Monjope, com seus painéis de azulejos do século XVIII, foi derrubada com autorização do IPHAN para que desse lugar a novos edifícios.

A proximidade do gosto estético e da valorização da tradição e a diferença de rede de relações intelectuais e ideológicas que esses dois pernambucanos,
8. Esse mesmo tipo de procedimento aparece na correspondência de Rodrigo com Augusto Meyer, que assume os serviços do SPHAN no Rio Grande do Sul. Ver a dissertação de Laura Xavier (2008). 
Gilberto Freyre e José Mariano Filho, montaram mereceria ser tema de uma pesquisa mais acurada - que não será feita aqui. Fica apenas a sugestão.

\section{"Modernismo regionalista" ou "provincianização modernizadora"}

A questão de ser Freyre um "modernista regionalista" ou um "provinciano moderno" volta e meia retorna à ordem do dia. Aqui, a comparação quase necessária é com o outro grande, Mário de Andrade. Gilberto Freyre aparece na literatura associado a uma perspectiva regionalista, entendida como parcial e provinciana, ao passo de Mário de Andrade é visto como grande inspirador e líder da modernização artística do Brasil. José Tavares Correia de Lira (2005), em seu artigo já mencionado, aborda comparativamente os dois autores, fazendo o contraponto entre o "turista aprendiz" e o "aprendiz de guia". Valéria Torres da Costa e Silva também vai analisar com atenção os dois autores (2006).

Para a autora, foi na releitura do ambiente intelectual nordestino na década de 20 que GF formou um olhar nostálgico e valorizou a tradição, ao mesmo tempo que desenvolveu uma sensibilidade estética moderna. Pretendeu inserir-se em um tipo de racionalidade que se apresentava como diferente da razão cartesiana, fundante do moderno. Nesse sentido, ele preza, admira formas culturais e de sociabilidade alternativas às da modernidade ocidental. Temia que a modernidade levasse ao apagamento das diferenças culturais e de tempos sociais distintos. Para apresentar o lugar singular de Freyre, Valéria Torres Costa e Silva vai explorar a diferença entre saudosismo e nostalgia (p. 76).

O saudosista é um restaurador. Alimenta o desejo de recriar um passado perdido. Vive a fantasia do retorno. O saudosista, se pudesse, congelaria o tempo em alguma idade de ouro que ficou para trás. O nostálgico (...) é, em contraposição, um ser deslocado, uma espécie de mediador entre o local e o universal, entre o passado e o futuro.

Talvez, a comparação da perspectiva de tempo em Gilberto Freyre e em Gustavo Barroso possa ajudar a compreender essa diferença. Barroso seria um tipo exemplar do saudosista, já que se detinha no culto da saudade e na confirmação

9. Sobre Gustavo Barroso, ver Chagas (2003) e Menezes (1986). do caráter militar da formação social brasileira? .

Nas primeiras décadas do século XX, Recife, assim como outras cidades do Brasil, está passando por processos de modernização urbana. A cidade sofre remodelação de seu traçado urbano e de sua arquitetura com a abertura de grandes avenidas, derrubada de edifícios, como arcos e igrejas, edifícios sem nenhuma relação com o colonial. É frente a essas interferências que crescem as reações tradicionalistas voltadas a proteger monumentos e edificações do passado 
contra a sanha dos arquitetos e engenheiros que pretendiam dar uma feição moderna à Veneza brasileira (p. 72). Os regionalistas estão contra os administradores públicos que mudam os antigos nomes de rua e abrem amplas avenidas, onde antes havia becos e ruas estreitas, tema mencionado, como já dissemos, no poema "Evocação do Recife", de Manuel Bandeira.

"A história do regionalismo mostra que ele surgiu e se desenvolveu em conflito com a modernização, a industrialização e a urbanização. Ele é, portanto, um fenômeno moderno e, paradoxalmente, urbano", nos diz Lígia Chiappini (1995). A primeira geração modernista saudou a modernização e, em seu entusiasmo um tanto ingênuo, fez do regionalismo o principal alvo a atacar. "Daí o ataque violento do próprio Mário de Andrade ao regionalismo como 'praga nacional', juízo que ele iria relativizar na maturidade".

Tanto GF, quanto Mário de Andrade estão, cada um a seu modo, procedendo a um enfrentamento da modernização. Cada um deles elabora respostas regionais ao processo - sempre desigual - de modernização. Valéria Torres Costa e Silva vai indicar as "surpreendentes" convergências entre os dois autores, ainda que seus contatos tenham sido sempre breves, suas trajetórias tangenciais. A autora fala de um silêncio entre eles. Entre os dois há figuras mediadoras, tais como Manuel Bandeira, Rodrigo Melo Franco de Andrade, Prudente de Moraes Neto, José Lins do Rego, Oswald de Andrade e Câmara Cascudo (p. 337-338). E lembra, era Câmara Cascudo quem punha Mário a par da agitação regionalista no Nordeste.

Mário de Andrade é tributário das diferentes representações sobre o homem rural paulista, construídas pela historiografia e pela literatura no primeiro quartel do século XX. No caso paulista, a crítica ao regionalismo deriva do deslumbramento com a metrópole cosmopolita. O caipira era visto como o atraso, a miséria, o oposto à grandiosidade paulista e a literatura do caipira não corresponde ao progresso de São Paulo.

A historiografia paulista, desde os fim do século XIX, buscou resgatar a contribuição dos costumes indígenas na cultura regional e as marcas características da personalidade do homem rústico paulista - o caboclo ou caipira. Fruto da miscigenação entre o branco e o índio, o caboclo é apresentado como o correspondente humilde do bandeirante. Versão equivalente ao sertanejo nordestino, o homem rústico paulista passa a ser tratado como reserva da nacionalidade ou como alicerce para a formação de uma raça forte (FERREIRA, 1999, p. 103). Essa representação, de reserva da nacionalidade, tem como pano de fundo o choque entre a cidade e o campo. E nela se fala do mundo estável das fazendas e das pequenas cidades do sertão em oposição ao tumulto e desagregação da 
emergente metrópole paulista.

O homem do interior, o trabalhador das áreas rurais, já recebera menção nas obras dos viajantes, dos cronistas que, durante o século XIX, visitaram o país. De modo geral, fora ressaltado o isolamento, a ignorância e a ociosidade em que viviam. Ou seja, destacavam-se as distâncias geográficas e socioculturais entre esses homens e os das cidades do litoral. Havia como que uma oscilação entre uma valorização positiva, que destacava a força, a autenticidade e a comunhão com a natureza. Do lado oposto, como traço negativo, aparecia a preguiça.

Nesse contexto, será ouvida a fala de Monteiro Lobato, denunciando a atividade predatória do caboclo, seu caráter nômade e sua imprevidência. Para Lobato, o caboclo - chamado de Jeca Tatu - pode ser bonito no romance, mas é feio na realidade. A natureza e suas facilidades tornam-se um obstáculo à regeneração do caboclo, já que não tem que enfrentar a hostilidade do ambiente.

Se, mais tarde, Lobato vai reescrever seu julgamento do caipira dizendo que ele não é preguiçoso e, sim, está doente, a versão desse tipo como o que encarna a preguiça está presente em Macunaíma, de Mário de Andrade, que também ironiza o discurso sanitarista assumido por Lobato.

O movimento literário regionalista, que está em curso no fim dos anos 1910 e início dos 1920, em São Paulo, se dedica à vida rural e à cultura caipira. Mais do que valorizar o índio - vestígio do romantismo - vai valorizar o mameluco e seu representante contemporâneo, o caipira. A literatura ficcional da época estava à procura das raízes nacionais, ocupada em buscar uma autenticidade nacional localizada no homem do interior, no folclore, nos mitos de origem.

O regionalismo literário que tematiza a vida rural e a cultura caipira recebeu de Mário de Andrade o epíteto de "velha praga" e foi considerado, durante muito tempo, pela crítica literária brasileira, como uma categoria ultrapassada.

Mesmo em uma visão mais complexa e nuançada da tradição interpretativa sobre os anos 1910 e 1920 do pensamento brasileiro, continuamos a nos defrontar com a versão que situa o modernismo como capitaneado por São Paulo e se opondo ao regionalismo provinciano. Segundo Valéria Torres da Costa e Silva (2006), a relação entre modernistas e regionalistas, entretanto, só ganha ares de polêmica quando GF e José Lins do Rego passam a falar de um movimento tradicionalista e, ao mesmo tempo, modernista em Pernambuco. Essa polêmica é aguçada quando, em 1952, GF publica o texto Manifesto Regionalista de 1926 e se apresenta como figura central em contraposição à versão de Joaquim Inojosa. A disputa passa a ser sobre quem exerceu influência e autoridade sobre uma geração de escritores da qual fizeram parte José Lins do Rego, Jorge de Lima, 
Graciliano Ramos, além de Ascenso Ferreira e de pintores como Cícero Dias, Lula Cardoso Ayres e Vicente do Rego Monteiro, entre outros.

Voltando à comparação entre Gilberto e Mário, Valéria Costa e Silva, vê semeIhanças entre os dois autores do ponto de vista da expressão artística (p. 356). Para ela, a passagem da Paulicéia Desvairada para Clã do Jaboti (1927) deve ser entendida como "uma substituição de horizontes geográficos: agora todo - Brasil interessa à nova técnica". Nesse livro, Mário visita, com seus poemas, vários pedaços do país, indo de Minas Gerais ao Rio Grande do Sul, de São Paulo à Amazônia, da cidade às matas (p. 363).

E, continua, quando GF elogia Mário, ele faz questão de qualificar o elogio dizendo que se trata do Mário de Andrade do "Noturno de Belo Horizonte". Ali, o poema define $o$

(...) Brasil através de suas raízes populares, tradicionais, a crítica à modernidade copiada, a opção por uma racionalidade anti-ocidental, o apreço, em contrapartida, pela imaginação, pelas crendices, pelo misticismo e pela afetividade colocam, definitivamente, Mário de Andrade e GF no mesmo barco. (p. 368)

Acompanhando a trajetória de vida e a produção dos dois, assim como a crítica, a autora vai mapeando possíveis explicações para as fortunas críticas e para a definição de campos opostos. Quanto à fabricação de autoimagem,

A diferença reside em que Mário opta por um low-profile e Gilberto assume descaradamente o auto-elogio. A desimportância que Mário de Andrade se auto-atribuía, por exemplo, na correspondência com Manuel Bandeira, destoa do trabalho minucioso de organização e catalogação da sua própria correspondência. (p. 373)

Para a autora Casa Grande e Senzala resulta de um grande esforço feito por GF para superar seu regionalismo e interferir de modo mais contundente e mais produtivo nos grandes debates do momento sobre os destinos do Brasil. Abandonar uma perspectiva local por uma nacional também se faz presente no Clã do Jabuti e em Macunaíma. Para além da plausibilidade dessa leitura, a distância entre os dois só cresce.

Regionalismo, localismo, bairrismo, nacionalismo fazem parte do caleidoscópio e do conflito cultural no qual se movem tanto Mário, quanto Gilberto.

\section{O regionalismo revisitado e outros regionalismos}


Em 1941, GF revisita o tema da região, publicando um livro que reúne textos de juventude. Trata-se de Região e Tradição. “Dos nove textos reunidos em Região e tradição, seis foram escritos entre o final dos anos 10 e o final dos anos $20-$ 'Adeus ao Colégio' (1917); 'Apologia pro Generatione Sua' (1924); 'Algumas notas sobre a pintura no Nordeste do Brasil' e 'Aspectos de um século de transição no Nordeste do Brasil' (1925); foram publicados no Livro do Nordeste - 'Região, tradição e cozinha' (1925); 'Região, Tradição e casa' (artigos do DP, publicados entre 1923-1926). Apenas os três últimos ensaios do livro datam dos anos 30. Um deles é 'Narcisismo Gaúcho' (1939), o outro é um discurso que Gilberto proferiu em jantar de homenagem a ele, 'Regresso à Província' (1936) e o derradeiro intitula-se 'Fidalgos pernambucanos' (1938)".

No prefácio do livro, ele volta a seus temas prediletos - a região ou o provincianismo - e dialoga, discute, questiona seus críticos. O prefácio é uma narrativa, uma conversa em terceira pessoa, ou seja, GF faz referência a si próprio como "o autor" e vai apresentando uma leitura de sua biografia e os embates que teve que enfrentar. "O autor", ao regressar ao Recife, em 1923, enfrentou o movimento modernista, inimigo à época "de toda a espécie de tradicionalismo e de toda forma de regionalismo". Se os "antiquários de província" o viam como iconoclasta, perigoso, "modernista", os modernistas mais ortodoxos do Rio e de São Paulo condenaram ou desprezaram a maior parte de suas atividades. E o que comporia sua atividade?

Artigos a favor da cozinha tradicional brasileira e das cozinhas regionais do país; a favor não da simples conservação mas do aproveitamento, pelos arquitetos mais jovens, dos valores da arquitetura tradicional e também dos estilos tradicionais de jardins e de parques à portuguesa, já acomodados à natureza e à vida brasileira; a favor dos estudos de história social e até íntima, nos arquivos públicos, de conventos, de irmandades e de família; a favor dos assuntos de negros, ameríndios, populares, regionais, folclóricos, provincianos e mesmo suburbanos como os melhores assuntos para os novos pintores, músicos, romancistas, pesquisadores e fotógrafos.

Seu regionalismo e seu tradicionalismo eram distantes tanto daquele modernismo, como das convenções dominantes.

Desde sua primeira viagem, em 1926, ao Rio e a São Paulo, foram criadas "afinidades profundas" com personalidades de "modernistas", com aqueles "interessados no folclore luso-brasileiro, em coisas de negros, de caboclos, de mestiços, tais como Manuel Bandeira, Prudente do Moraes Neto, Rodrigo Melo Franco de Andrade, Carlos Drummond de Andrade, Sérgio Buarque de Holanda, Couto de Barros, Rubens Borba de Moraes, Jayme Ovalle, Afonso Arinos de Melo Franco. 
O regionalismo tradicionalista, que, desde 1923, se afirmou no Recife, teve também coincidências com o modernismo quanto à técnica experimental e foi também reação contra convenções do classicismo, do academicismo e do purismo lusitano. O "movimento do Norte" (sic) se fez presente na literatura, na pintura e na música.

Na ficção, os romances de José Lins do Rego são a "expressão mais forte e mais pura" da conciliação do regional literário e artístico com o modernismo.

Os renovadores do Nordeste viam o regional como "gosto pelo assunto vivo os homens vistos de perto, tanto no tempo, como no espaço". E esclarece: eles não desprezavam o público, "esforçaram-se por se exprimirem de modo o mais simples possível", "procuraram escrever de maneira a mais próxima possível da língua falada".

Freyre faz uma associação entre aqueles renovadores do Nordeste, entre os quais menciona José e Clarival Valladares e os intelectuais russos conhecidos por "eslavóficos", em sua luta contra a excessiva europeização ou ianquização do trajo popular, da casa, do jardim, do móvel e da culinária.

Os renovadores foram chamados também de "românticos", "neo-românticos", ou de "realistas românticos", nomeações aceitas pelo autor, na medida em que estavam contra um "universalismo estático" e, sim, mais próximos do romantismo enquanto reconhecimento da espontaneidade, da diversidade, da variedade no tempo e no espaço.

Essa versão é reafirmada em "A condição de provinciano no Brasil" é título de artigo que GF publica na revista "Cultura Política"10 em 1942. Ali, reafirma que província e provinciano representam algo de básico, de fundamental para a vida intelectual e estética e para a organização e desenvolvimento da nossa cultura. A condição de provinciano é "uma condição de vitalidade, de autenticidade, de vigor, de permanência e de espontaneidade". A unidade não deve abafar a diversidade provinciana, as expressões regionais da chamada "realidade brasileira" (p. 13).

Os ideólogos e práticos da República criaram o "estadualismo", entendido como uma política perigosa de autonomias estaduais para satisfazer interesses de grupos que, sob o manto dos favores da União a Estados dominantes, leva a um processo de "balcanização" da América portuguesa. O provincianismo está e deve estar na base do federalismo e transnacionalismo da cultura.

Reconhece a necessidade da cooperação inter-regional no Brasil, "onde as regiões existem por natureza, por condições geográficas e agrológica e por força do desenvolvimento histórico e de cultura" (p. 14).
10. Revista oficial do Estado Novo publicada pelo DIP, trata das mais importantes questões da época. 
O esforço regional ou provinciano "pode e deve ser o melhor elemento vivificador da unidade brasileira". A unidade que convém ao Brasil é da cooperação inter-regional, da cultura da vida. A ordem não deve ser "sinônimo de estagnação ou mesmo de regularidade, de simetria" que esmague a espontaneidade da província com "um critério único de urbanismo, de paisagismo, de pedagogismo rígido". A literatura, a arte, a cultura devem exprimir as diversas energias das províncias que constituem o Brasil.

E conclui, afirmando o "ajustamento orgânico" das regiões, "como membros de um só corpo", como vem sendo feito nos últimos 10 anos pelo Presidente Getúlio Vargas e que enriquece o todo cultural e o povo.

Para alguns autores, há uma questão subjacente quando procedem à análise de GF: saber se ele superou ou não seu regionalismo, se adotou uma perspectiva nacional. Penso que superar seu regionalismo não fazia sentido e não era questão para o autor!

Conforme já mencionei, Gilberto Freyre vai construir uma relação forte com os baianos e integrar a Bahia como matriz da brasilidade nordestina. A proliferação de outros regionalismos apenas confirma o regionalismo como "elemento vivificador da unidade brasileira". Assim, o mesmo princípio de defesa e valorização do regional está presente em suas conferências e artigos referentes à sua viagem ao Rio Grande do Sul e em relação aos gaúchos (NEDEL, 2007).

Estava eu começando a elaborar este texto, retomando algumas leituras que me ajudaram a situar Freyre como figura central da valorização do provincianismo, de construção do regionalismo como algo tradicional e moderno simultaneamente, quando me defrontei com outra perspectiva: ao mencionar a importância do regionalismo e a proliferação de movimentos culturais do Recife, ouvi um comentário que me fez refletir sobre o assunto. Disse um conhecido meu cearense: o problema é que recebemos a versão do nordeste através da lente que "pernambucanizou" tudo... E, assim, as manifestações emanadas de outros centros como Fortaleza ou Belém foram e são, por assim dizer, apagadas, esquecidas.

Abstract: This article presents different readings of the works by Gilberto Freyre from the 1930s to the present day. It shows the importance of his experiences as a traveler for the adoption of an endogenous and exogenous perspective when observing cities. The impact felt upon his return to Pernambuco in the 1920s was furthered by his observation of the process of urbanization which threatened to disfigure the old quarters of the city of Recife. His patrimonialist vision solidified in the organization of Livro do Nordeste (1925), celebrating the centennial 
of the Diário de Pernambuco, in which Manuel Bandeira published "Evocation of Recife". Freyre and Bandeira, close friends and fellow journeymen, take turns writing guides and poems about cities. At last, the article returns to the concepts of "regionalist modernism" or "modernist provincialization" in order to identify within the oeuvre of Gilberto Freyre an "other" modernism, distinct from those which evolved from modernism in the state of São Paulo.

Keywords: invention of the Northeast; travels in Gilberto Freyre; city guides; regionalismo; an "other" modernism.

\section{Referências Bibliográficas}

Almeida, José Mauricio Gomes De (2003) "Regionalismo e modernismo: as duas faces da renovação cultural dos anos 20" in Ethel V. Kosminsky, Claude Lépine \& Fernanda Areas Peixoto. "Gilberto Freyre em quatro tempos". Bauru, SP: Edusc.

Araújo, Ricardo Benzaquen de (1994) Guerra e Paz: Casa-Grande e Senzala e a obra de GF nos anos 30. Rio de Janeiro: 34 Letras.

(1997) "Deuses em miniatura: notas sobre genialidade e melancolia em Gilberto Freyre" in Navegar é preciso, viver: escritos para Silviano Santiago. Belo Horizonte: UFMG; Salvador: EDUFBA; Niterói: EDUFF.

Arruda, Maria Arminda do Nascimento (1986-1987) "A temática regional: considerações historiográficas". Anais do Museu Paulista. USP, São Paulo, Tomo XXXV: 156-166.

Calazans, Rejane (2007) “Ambivalências: o Nordeste nas obras de Gilberto Freyre e Celso Furtado". Revista Brasileira de Ciências Sociais, vol. 22, n. 64, Junho.

Chagas, Mário (2003) Imaginação museal: museu, memória e poder em Gustavo Barroso, Gilberto Freyre e Darcy Ribeiro, UERJ (tese de doutorado) PPCIS.

Costa E Silva, Valéria Torres da (2006) A Modernidade nos Trópicos: Gilberto Freyre e os debates em torno do nacional. Ph. D. Dissertation. University of California, Berkeley. (Publicada em livro com mesmo título, Recife: Carpe Diem, 2009).

Daou, Ana Maria (2001) "Tipos e aspectos do Brasil: imagens em imagem do Brasil" in Zeny Rozendahl \& Roberto Lobato Corrêa (orgs.), Paisagem, imaginário e espaço. Rio de Janeiro, Eduerj. 
Dias, Silvana Moreli Vicent (2008) "A província, das aporias às experiências repartidas: Gilberto Freyre e Manuel Bandeira no Brasil das décadas de 20 e 30" in Maria Emilia Prado (org.) Tradição e modernidade no mundo ibero-americano. Rio de Janeiro, de 28 a 30 de maio. CD Atas do V Colóquio Internacional.

Ferreira, Antonio Celso (1999) "Vida (e morte?) da epopéia paulista" in Antonio Celso Ferreira, Tânia Regina de Luca, Zilda Grícoli lokoi. Encontros com a História: percursos históricos e historiográficos de São Paulo. São Paulo: UNESP, PAPESP, ANPUH/SP.

Freyre, Gilberto (2007) Guia prático, histórico e sentimental da cidade do Recife. Rio de Janeiro: Global [1. edição: 1934].

(1942) "A condição de provinciano". Cultura Política, ano II, n. 15, maio: 13-16. [Revista disponível no site do Cpdoc].

(1968) "Prefácio". Região e tradição. Ilustrado por Cícero Dias. Rio de Janeiro: José Olympio, 1941 (Documentos brasileiros, 29). 2. ed. Rio de Janeiro: Reccord.

(1952) "Manifesto Regionalista de 1926". Boletim do Instituto Joaquim Nabuco de Pesquisas Sociais. Recife, v. 1, n. 1: 21-43 [Texto disponível na Biblioteca Virtual Gilberto Freyre].

Galvão, Walnice Nogueira (2000) "Anotações à margem do regionalismo". Literatura e sociedade. São Paulo, n. 5: 44-55.

Giucci, Guillermo (2000) "Gilberto Freyre: as cidades" in Fátima Quintas (org.), Seminário Internacional Novo Mundo nos Trópicos. Recife, CD.

Kessel, Carlos (2002) Vanguarda efêmera: arquitetura neocolonial na Semana de Arte Moderna de 1922. Estudos Históricos, Rio de Janeiro, Cpdoc, n. 30.

(2008) Arquitetura neocolonial no Brasil; entre o pastiche e a modernidade. Rio de Janeiro: Jauá/Faperj.

Leite, Lígia Chiappini De Moraes (1995) Do beco ao belo: dez teses sobre o regionalismo na literatura. Estudos Históricos, vol. 8, n. 15: 153-159.

(1994) "Velha praga? Regionalismo literário brasileiro" in Ana Pizarro (org), América Latina: palavra, literatura e cultura. vol.1: 665-702, Campinas, UNICAMP.

Lira, José Tavares Correia de (2005) "Naufrágio e galanteio: viagem, cultura e cidade em Mário de Andrade e Gilberto Freyre". Revista Brasileira de Ciências Sociais, vol. 20, n. 50, fevereiro. 
Menezes, Eduardo Diatahy B. de (1986) "A dialética do rifle e do rosário - apontamentos para uma releitura do cangaço nordestino" in Vicente da Silva, S. (org.), A igreja e a questão agrária no Nordeste. São Paulo: Paulinas.

Nedel, Letícia (2007) “A recepção da obra de Gilberto Freyre no Rio Grande do Sul". Mana, vol. 13, n. 1: 85-118.

(2007) "Saber(-se) local: configurações do "regionalismo" no campo intelectual sul-rio-grandense". GT 16: Pensamento Social no Brasil XIII Congresso Brasileiro de Sociologia. 29 de maio a 1 de junho, UFPE.

Nicolazzi, Fernando (2006) "Gilberto Freyre viajante: olhos seus, olhares alheios" in Manuel Luiz Salgado Guimarães (org.), Estudos sobre a escrita da História. Rio de Janeiro: 7Letras.

Pallardes-Burke, Maria Lúcia (2003) "Gilberto Freyre: um nordestino vitoriano" in Ethel V. Kosminsky, Claude Lépine, \& Fernanda Áreas Peixoto. Gilberto Freyre em quatro tempos. Bauru, SP:/Edusc.

(2000) "Ingleses no Brasil: um quase-manifesto" in Fátima Quintas (org.), Seminário Internacional Novo Mundo nos Trópicos. Recife, CD.

Ribeiro, Rodrigo Alves (2008) Moradas da Memória: uma história social da casamuseu de Gilberto Freyre. Rio de Janeiro: MinC/IPHAN/DEMU.

Silva, Marcos António Da (org.) (1990) República em migalhas. História regional e local. São Paulo: Marco Zero/CNPq.

Sorá, Gustavo (1998) "A construção sociológica de uma posição regionalista: reflexões sobre a edição e recepção de Casa Grande \& Senzala de Gilberto Freyre". $R B C S$, vol. 13, n. 36, fevereiro.

Tuna, Gustavo Henrique (2003) Viagens e viajantes em Gilberto Freyre. Dissertação de mestrado. Unicamp.

Veloso, Marisa (2000) "Gilberto Freyre e o horizonte do modernismo". Revista Sociedade \& Estado. Brasília, vol. XV, n. 2: .363-386.

Vianna, Hermano (1995) O mistério do samba. Rio de Janeiro, Jorge Zahar.

Xavier, Laura (2008) Patrimônio em prosa e verso: a correspondência de Rodrigo Melo Franco para Augusto Meyer. Dissertação de Mestrado, PPHPBC, Cpdoc. 